\title{
PENGARUH STRUKTUR MODAL, MANAJEMEN LABA, LIKUIDITAS DAN BEBAN PAJAK TANGGUHAN TERHADAP KINERJA KEUANGAN
}

\author{
Desy Ratma Belia Astari; Riana Rachmawati Dewi²; Purnama Siddi3 \\ Fakultas Ekonomi Universitas Islam Batik Surakarta ${ }^{1,2,3}$
}

$\underline{\text { beliaastari196@gmail.com }}^{1}$; $\underline{\text { riana rd40@yahoo.com }}^{2}$; purnamasiddi.1104@gmail.com ${ }^{3}$

\begin{abstract}
ABSTRAK
Kinerja keuangan perusahaan merupakan penentuan ukuran-ukuran yang dapat digunakan untuk menjadi tolak ukur keberhasilan perusahaan menghasilkan laba. Penelitian ini bertujuan untuk mengetahui pengaruh struktur modal, manajemen laba, likuiditas dan beban pajak tangguhan terhadap kinerja keuangan. Perbedaan dengan penelitian sebelumnya terletak pada jenis perusahaan, jumlah sampel yang digunakan dan periode penelitian. Populasi penelitian ini adalah 34 perusahaan manufaktur sektor industri barang konsumsi sub sektor makanan dan minuman yang terdaftar di Bursa Efek Indonesia pada tahun 2016-2019. Teknik pengambilan sampel dalam penelitian ini adalah teknik purposive sampling sehingga dihasilkan sampel penelitian sebanyak 12 perusahaan dengan jumlah sampel penelitian yang telah memenuhi kriteria. Data yang digunakan dalam penelitian ini adalah data sekunder berupa annual report perusahaan. Analisis data yang digunakan penelitian ini adalah analisis regresi linier berganda. Perhitungan ${ }_{1}$ dalam penelitian ini menggunakan program SPSS versi 20. Hasil penelitian ini menunjukkan bahwa struktur modal dan manajemen laba tidak berpengaruh terhadap kinerja keuangan. Sedangkan likuiditas berpengaruh terhadap kinerja keuangan dan beban pajak tangguhan berpengaruh terhadap kinerja keuangan.
\end{abstract}

Kata Kunci : Struktur Modal, Manajemen Laba, Likuiditas, Beban Pajak Tangguhan dan Kinerja Keuangan.

\section{Abstract}

The company's financial performance is the determination of measures that can be used to measure the company's success in generating profits. This study aims to determine the effect of capital structure, earnings management, liquidity and deferred tax expense on financial performance. The difference with previous studies lies in the type of company, the number of samples used and the study period. The population of this study were 34 manufacturing companies in the food and beverage sub-sector, which were listed on the Indonesia Stock Exchange in 2016-2019. The sampling technique in this study was purposive sampling technique so that the research sample was 12 companies with the number of research samples that met the criteria. The data used in this research is secondary data in the form of company annual reports. The data analysis used in this study is multiple linear regression analysis. The calculation in this study uses the SPSS version 20 program. The results of this study indicate that capital structure and earnings management have no effect on financial performance. Meanwhile, liquidity has effect on financial performance and deferred tax expense has effect on financial performance.

Keywords : Capital Structure, Profit Management, Liquidity, Deferred Tax Expenses and Financial Performance. 
Diterima: 30 Maret 2021; Direvisi: 6 April 2021; Diterbitkan: 20 April 2021

\section{PENDAHULUAN}

Perusahaan adalah suatu wadah yang berisi kegiatan bisnis yang dilakukan baik dalam bentuk barang maupun jasa, setiap perusahaan memiliki rencana masa depan tersendiri untuk mencapai tujuan perusahaan, tujuan utama setiap perusahaan pada umumnya adalah untuk mencapai laba yang maksimal setiap tahunnya sesua dengan target yang ditetapkan untuk meningkatkan pertumbuhan perusahaan.

Untuk mencapai tujuan tersebut perusahaan memerlukan dana untuk dapat menjalankan setiap kegiatan operasionalnya, Sumber pendanaan di dalam suatu perusahaan dibagi menjadi dua kategori yaitu pendanaan internal dan pendanaan eksternal. Pendanaan internal dapat diperoleh dari sumber laba ditahan dan depresiasi, sedangkan pendanaan eksternal dapat diperoleh dari penerbitan saham dan obligasi baru (Gustian 2017).

Kinerja keuangan perusahaan merupakan penentuan ukuran-ukuran yang dapat digunakan untuk menjadi tolak ukur keberhasilan perusahaan menghasilkan laba (Sucipto, 2003). Kinerja keuangan yang baik dapat membantu manajemen dalam pencapaian tujuan perusahaan. Semakin tinggi kinerja perusahaan, semakin tinggi pula nilai perusahaan di mata investor. Untuk menukur kinerja keuangan penulis menggunakan Return on Equity (ROE). Rasio ini menunjukan efisiensi penggunaan modal sendiri. Semakin tinggi rasio ini semakin baik (Purwana dan Hidayat, 2017:172).

Struktur modal merupakan komposisi antara hutang jangka panjang dan modal sendiri dari perusahaan itu sendiri maupun modal dari luar perusahaan dengan adanya modal tersebut perusahaan dapat mengoptimalkan modal dengan baik agar perusahaan dapat memperoleh keuntungan, dengan adanya keuntungan yang diperoleh perusahaan maka tujuan perusahaan untuk memperoleh laba tercapai (Riyanto, 2001). Untuk mengukur strukur modal guna mengetahui setiap rupiah modal sendiri yang digunakan sebagai jaminan utang dapat menggunakan Debt to Equity Ratio (DER) (Kasmir, 2015).

Manajemen laba merupakan suatu tindakan yang dilakukan oleh manajemen dengan tujuan untuk memaksimumkan, meminimumkan atau untuk melakukan perataan laba pada perusahaan dengan tujuan laporan keuangan perusahaan terlihat baik (Scott dan William, 2009). Manajer dapat memanipulasi laporan keuangan dengan efisien (William dan Scott, 2000).

Menurut Hani (2015) likuiditas menunjukkan kemampuan perusahaan dalam memenuhi kewajiban-kewajiban yang segera dapat dicairkan atau yang sudah jatuh tempo. Tingkat aktivitas perusahaan dapat menurun apabila likuiditas yang dimiliki perusahaan terlalu tinggi, hal ini menunjukkan bahwa terdapat banyak dana atau aset yang menganggur.

\begin{tabular}{lccc}
\multicolumn{1}{c}{ Menurut Waluyo } & (2014) & Pajak \\
Tangguhan & sebagai & jumlah & Pajak \\
Penghasilan & yang & terpulihkan & pada \\
periode & mendatang & sebagai & akibat \\
perbedaan & temporer & yang & boleh \\
dikurangkan dari sisa & kerugian & yang \\
dapat dikompensasikan. & Beban & atau \\
manfaat pajak tangguhan adalah jumlah
\end{tabular}


beban atau manfaat pajak tangguhan yang muncul akibat adanya pengakuan atas kewajiban atau aset pajak tangguhan (Tandio dan Lidyawati, 2014)

Penelitian ini bertujuan untuk menguji dan menganalisis pengaruh struktur modal, manajemen laba, likuiditas dan beban pajak tangguhan terhadap kinerja keuangan. Sampel yang digunakan dalam penelitian ini adalah perusahaan manufaktur sektor industri barang konsumsi sub sektor makanan dan minuman yang terdaftar di Bursa Efek Indonesia tahun 2016-2019.

\section{LANDASAN TEORI}

\section{Teori Keagenan (Agency Theory)}

Jensen dan Meckling (1976), menyatakan bahwal hubungan agensi terjadi ketika satu orangatau lebih pemegang saham (principal) mempekerjakan orang lain (agent) untuk memberikan jasa dan kemudian mendelegasikan wewenang pengambilan keputusan kepada agent tersebut. Dalam teori agensi, manajemen akan mengupayakan agar kinerja perusahaan terlihat baik di hadapan pemilik. Untuk membuat kinerja terlihat baik maka pihak manajemen akan melakukan manajemen laba untuk tujuan itu.

\section{Kinerja Keuangan}

Menurut Fahmi (2011), kinerja keuangan adalah suatu analisis yang dilakukan untuk melihat sejauh mana suatu perusahaan telah melaksanakan dengan menggunakan aturan-aturan pelaksanaan keuangan secara baik dan benar. Kinerja perusahaan dapat diukur dengan menganalisa dan mengevaluasi laporan keuangan. Informasi posisi keuangan dan kinerja keuangan di masa lalu seringkali digunakan sebagai dasar untuk memprediksi posisi keuangan dan kinerja di masa depan dan hal-hal lain yang langsung menarik perhatian pemakai seperti dividen, upah, pergerakan harga sekuritas dan kemampuan perusahaan untuk memenuhi komitmennya.

Dalam penelitian ini, rasio profitabilitas diukur dengan return on equity. Return on Equity (ROE) merupakan rasio yang menunjukkan kemampuan perusahaan dalam menghasilkan laba bersih untuk pengembalian ekuitas pemegang saham dan ROE merupakan rasio keuangan yang digunakan untuk mengukur profitabilitas dari ekuitas (Kusumajaya, 2011).

$$
\begin{aligned}
& \begin{array}{l}
\text { Menurut } \\
\text { pengukuran } \\
\text { diukur dengan: }
\end{array} \\
& \text { kinerja keuangan dapat } \\
& \text { Return on Equity }=\frac{\text { Laba Bersih }}{\text { Ekuitas }}
\end{aligned}
$$

\section{Struktur Modal}

Struktur modal merupakan komposisi antara hutang jangka panjang dan modal sendiri dari perusahaan itu sendiri maupun modal dari luar perusahaan dengan adanya modal tersebut perusahaan dapat mengoptimalkan modal dengan baik agar perusahaan dapat memperoleh keuntungan, dengan adanya keuntungan yang diperoleh perusahaan maka tujuan perusahaan untuk memperoleh laba tercapai (Riyanto, 2001)

Apabila perusahaan lebih banyak menggunakan hutang risiko yang ditanggung oleh pemegang saham, dengan memperbesar tingkat pengembalian investasi yang ditanggung pemegang saham serta memperbesar 
tingkat pengembalian investasi (Brigham dan Houston, 2001).

Menurut Kasmir (2015:158) Debt to equity ratio (DER) dapat dihitung dengan rumus sebagai berikut:

$$
\text { Debt to Equity Ratio }=\frac{\text { Total Utang }}{\text { Ekuitas }}
$$

\section{Manajemen Laba}

Manajemen laba merupakan suatu tindakan yang dilakukan oleh manajemen dengan tujuan untuk memaksimumkan, meminimumkan atau untuk melakukan perataan laba pada perusahaan dengan tujuan laporan keuangan perusahaan terlihat baik (Scott dan William, 2009).

Subramanyam dan John (2014) berpendapat bahwa manajemen laba terjadi karena beberapa alasan, seperti untuk meningkatkan kompensasi, menghindari persyaratan utang, memenuhi ramalan analis, dan memengaruhi harga saham.

Penghitungan manajemen laba dalam penelitian ini menggunakan model Jones dimodifikasi (modified jones model). Untuk menghitung manajemen laba dapat dilakukan dengan metode sebagai berikut:

1. Menentukan nilai Total Accrual (TAC)

$$
T A C_{i t}=N_{i t}-C F O_{i t}
$$

2. Total Accrual yang diestimasi dengan persamaan regresi OLS (Ordinary Least Square)

$$
\frac{T A C_{i t}}{\mathrm{~A}_{\mathrm{it}-1}}=\beta 1\left(\frac{1}{A_{i t-1}}\right)+\beta 2\left(\frac{\Delta R E V_{i t}}{A_{i t-1}}\right)+\beta 3\left(\frac{P P E_{i t}}{A_{i t-1}}\right)+e
$$

3. Menghitung Non Discretionary Accruals (NDAC) sebagai berikut :

$$
N D A_{i t}=\beta 1\left(\frac{1}{A_{i t-1}}\right)+\beta 2\left(\frac{\Delta R E V_{i t}}{A_{i t-1}}-\frac{\Delta R E C_{i t}}{A_{i t-1}}\right)+\beta 3\left(\frac{P P E_{i t}}{A_{i t-1}}\right)
$$

4. Dengan menggunakan koefisien regresi diatas nilai Discretionary Current Accruals (DAC) dapat dihitung dengan rumus:

$$
D A C_{i t}=\left(\frac{T A C_{i t}}{A_{i t-1}}\right)-N D A C_{i t}
$$

Keterangan :

$N_{i t} \quad$ : Net Income perusahaan i pada tahun $\mathrm{t}$

$\mathrm{CFO}_{\text {it }}$ : Aliran Kas dari aktivitas operasi perusahaan i pada tahun $\mathrm{t}$

$T A C_{i t}$ : Total Accrual perusahaan i pada tahun $\mathrm{t}$

$D A C_{i t}$ : Discretionary Accruals perusahaan i pada tahun $\mathrm{t}$

$N D A_{\text {it }}$ : Non Discreationary Accruals perusahaan i padata hun $\mathrm{t}$

$A_{\text {it-1 }} \quad$ : Total Asset perusahaan i pada $\mathrm{t}_{-1}$

$\triangle R E V_{i t}$ : Perubahan pendapatan perusahaan i pada tahun $\mathrm{t}_{-1}$

$\triangle R E C_{i t}$ : Perubahan piutang perusahaan i pada tahun $\mathrm{t}_{-1}$

$P P E_{i t}$ : Property, Plant, Equipment perusahaan i pada tahun $\mathrm{t}$

$\beta 1 \beta 2 \beta 3$ : Koefisien Regresi

\section{Likuiditas}

Likuiditas menggambarkan kemampuan suatu perusahaan untuk memenuhi kewajiban finansial jangka pendek tepat pada waktunya. Apabila perusahaan saat ditagih maka perusahaan harus mampu membayar utang pada saat jatuh tempo (S. Munawir, 1981 dikutib dalam Erawati dan Ndoen, 2019). Rasio lancar dapat dihitung dengan rumus sebagai berikut (Kasmir):

$$
\text { Current Ratio }=\frac{\text { Aktiva Lancar }}{\text { Utang Lancar }}
$$




\section{Beban Pajak Tangguhan}

Kewajiban pajak tangguhan ini timbul karena adanya perbedaan sementara dalam hal pengakuan pendapatan dan beban antara laba akuntansi dan laba pajak. Laba menurut akuntansi (laba komersial) diukur berdasarkan akrual (accrual basic), sedangkan laba menurut pajak (laba kena pajak atau laba fiskal) berpatokan pada dasar kas (cash basic). Dinamakan perbedaan sementara karena secara keseluruhan (setelah memalui beberapa periode), dampak dari perbedaan pengakuan tersebut terhadap laba akuntansi maupun laba menurut pajak akan sama (Hery, 2014) (Soehardi \& Untari, 2020) .

Menurut PSAK (2010) pajak tangguhan dapat dihitung dengan cara:

$$
\text { Different } T a x=\frac{D T E_{i t}}{A T A_{i t}}
$$

Keterangan

DTE $_{\text {it }}=$ Beban Pajak Tangguhan

ATA $_{\text {it }}=$ Total Aset perusahaan i tahun $\mathrm{t}-1$

\section{Keranga Penelitian}

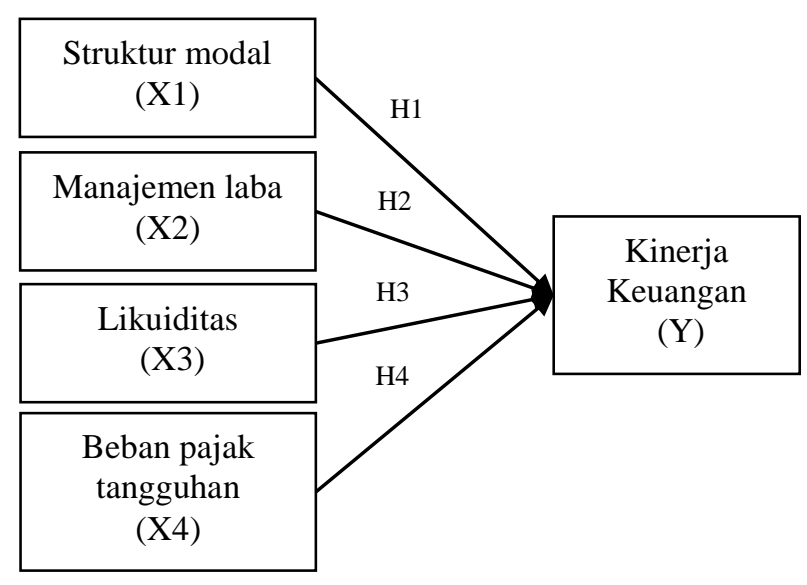

\section{Hipotesis}

H1 : Struktur modal berpengaruh terhadap kinerja keuangan;

H2: Manajemen laba berpengaruh terhadap kinerja keuangan;

H3: Likuiditas berpengaruh terhadap kinerja keuangan;

$\mathrm{H}_{4}$ : Beban pajak tangguhan berpengaruh terhadap kinerja keuangan.

\section{METODE PENELITIAN}

Metode penelitian ini adalah penelitian kuantitatif dengan analisis regresi linier berganda. Pengolahan data menggunakan software SPSS versi 20. Populasi yang digunakan dalam penelitian ini adalah perusahaan sub sektor barang konsumsi yang terdaftar di Bursa Efek Indonesia (BEI) tahun 2016-2019 sebanyak 12 perusahaan. Kriteria sampel ditentukan dengan purposive sampling terdiri dari perusahaan manufaktur sektor industri barang konsumsi sub sektor makanan dan minuman yang terdaftar di BEI 20162019; Perusahaan manufaktur sektor industri barang konsumsi sub sektor makanan dan minuman yangi tidak mempublikasikan annual reportnya secara berturut-turut selama 2016-2019; Perusahaan manufaktur sektor industri barang konsumsi sub sektor makanan dan minuman yang mengalami kerugian selama 2016-2019 ; Perusahaan manufaktur sektor industri barang konsumsi sub sektor makanan dan minuman yang tidak menggunakan mata uang rupiah dalam laporan keuangannya selama 2016-2019. Dari kriteria tersebut didapat sampel sebanyak 35 sampel data perusahaan. 


\section{HASIL PENELITIAN DAN PEMBAHASAN}

Tabel 1 Kriteria Penuntuan Sampel

\begin{tabular}{lc}
\hline \multicolumn{1}{c}{ Kriteria Sampel } & Jumlah \\
\hline $\begin{array}{l}\text { Perusahaan manufaktur sector industri } \\
\text { barang konsumsi sub sektor makanan dan } \\
\text { minuman yang terdaftar di BEI 2016- }\end{array}$ & 19 \\
2019 & \\
\hline $\begin{array}{l}\text { Perusahaan manufaktur sektor industri } \\
\text { barang konsumsi sub sektor makanan dan } \\
\text { minuman yang tidak mempublikasikan }\end{array}$ & $(3)$ \\
annual report secara berturut-turut \\
periode 2016-2019
\end{tabular}

Daftar perusahaan yang digunakan dalam penelitian ini terdiri dari 12 perusahaan manufaktur sektor industri barang konsumsi sub sektor makanan dan minuman di Bursa Efek Indonesia dengan periode 2016-2019 yang dapat dilihat pada tabel 2 berikut :

Tabel 2 Daftar Sampel Penelitian

\begin{tabular}{|c|c|c|}
\hline No & $\begin{array}{c}\text { Kode } \\
\text { Saham }\end{array}$ & Nama Emiten \\
\hline 1 & ADES & PT Akasha Wira International Tbk. \\
\hline 2 & BUDI & PT Budi Starch \& Sweetener Tbk. \\
\hline 3 & CEKA & PT Wilmar Cahaya Indonesia Tbk. \\
\hline 4 & DLTA & PT Delta Djakarta Tbk. \\
\hline 5 & ICBP & $\begin{array}{l}\text { PT Indofood CBP Sukses Makmur } \\
\text { Tbk. }\end{array}$ \\
\hline 6 & INDF & PT Indofood Sukses Makmur Tbk. \\
\hline 7 & MLBI & PT Multi Bintang Indonesia Tbk. \\
\hline
\end{tabular}

8 MYOR PT Mayora Indah Tbk.

9 ROTI PT Nippon Indosari Corpindo Tbk.

10 STTP PT Siantar Top Tbk.

11 TBLA PT Tembaga Mulia Semanan Tbk.

ULTJ PT Ultra Jaya Milk Industry \&

12 ULTJ Trading Company Tbk.

Sumber :Pengolahan Data, (2021)

\section{Hasil statistik deskriptif}

Tabel 3 Hasil Uji Statistik Deskriptif

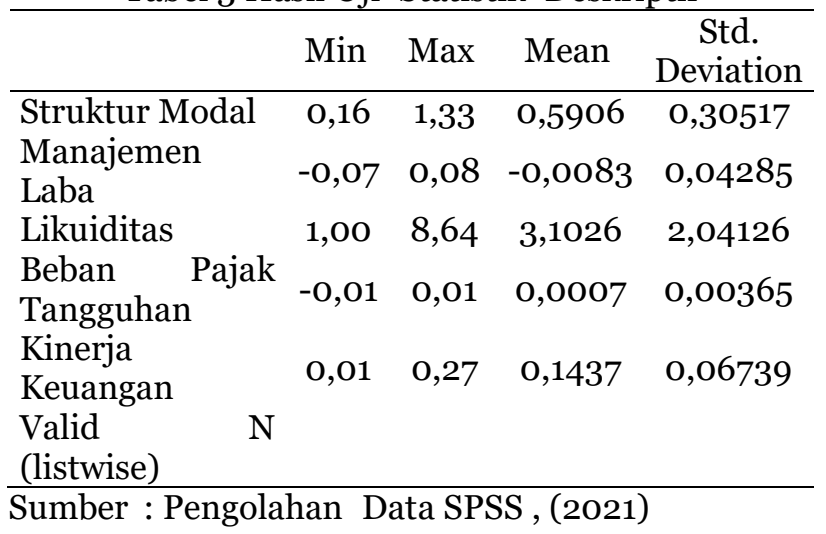

Dari tabel 3 diatas, variabel nilai Struktur Modal terkecil sebesar 0,16 nilai maksimumnya sebesar 1,33 dengan ratarata Struktur Modal sebesar 0,5906 dan standar deviasinya 0,30517 . Untuk variabel Manajemen Laba nilai terkecil sebesar 0,07 nilai terbesar sebesar 0,08 dengan rata-rata Manajemen Laba sebesar o,0083 dan standar deviasinya 0,04285 . Nilai variabel Likuiditas nilai minimumnya sebesar 1,00 nilai maksimum sebesar 8,64 dengan rata-rata Likuiditas sebesar 3,1026 dan standar deviasinya 2,04126. Untuk variabel Beban Pajak Tangguhan nilai terkecil sebesar -0,01 nilai terbesar sebesar o,01 dengan rata-rata Beban Pajak Tangguhan sebesar 0,0007 dan standar deviasinya 0,00365. Sedangkan variabel Kinerja Keuangan nilai minimumnya sebesar 0,01 nilai maksimumnya sebesar 0,27 dengan rata-rata Kinerja Keuangan sebesar 0,1437 dan standar deviasinya o,06739. 


\section{Uji Asumsi Klasik}

\section{Hasil Uji Normalitas}

Tabel 4 Hasil Uji Normalitas

\begin{tabular}{ccc}
\hline $\begin{array}{c}\text { Sig. (2- } \\
\text { tailed) }\end{array}$ & Standar & Kesimpulan \\
\hline 0,873 & $>0,05$ & Data terdistribusi normal \\
\hline
\end{tabular}

Sumber : Pengolahan Data SPSS, (2021)

Dari tabel 4 diatas dapat diketahui bahwa nilai signifikansi (Asymp.Sig) 2tailed sebesar 0,873. Karena nilai signifikansi lebih dari 0,05 , nilai residual terdistribusi dengan normal.

\section{Hasil Uji Multikolinieritas}

Tabel 5 Hasil Uji Multikolinieritas

\begin{tabular}{lccc}
\hline \multicolumn{1}{c}{ Variabel } & Tolerance & VIF & Keterangan \\
\hline $\begin{array}{l}\text { Struktur } \\
\text { Modal }\end{array}$ & 0,495 & 2,021 & $\begin{array}{c}\text { Tidak terjadi } \\
\text { multikolinieritas } \\
\text { Manajemen }\end{array}$ \\
$\begin{array}{l}\text { Laba } \\
\text { Lidak terjadi } \\
\text { Likuiditas }\end{array}$ & 0,969 & 1,032 & $\begin{array}{c}\text { multikolinieritas } \\
\text { Tidak terjadi }\end{array}$ \\
$\begin{array}{l}\text { Beban Pajak } \\
\text { Tangguhan }\end{array}$ & 0,956 & $\mathbf{1 , 0 4 5}$ & $\begin{array}{c}\text { Tidak terjadi } \\
\text { multikolinieritas } \\
\text { multikolinieritas }\end{array}$ \\
\hline
\end{tabular}

Sumber : Pengolahan Data SPSS, (2021)

Dari tabel 5 di atas dapat dilihat bahwa nilai tolerance keempat variabel lebih dari o,10 dan nilai VIF kurang dari 10. Maka dapat disimpulkan bahwa tidak terjadi multikolinieritas antar variabel bebas.

\section{Hasil Uji Autokorelasi}

Tabel 6 Hasil Uji Autokorelasi

\begin{tabular}{cccc}
\hline $\mathrm{dU}<$ & $\mathrm{DW}$ & $<4$-dU & Keterangan \\
\hline $1,7259<$ & 1,784 & $<2,2741$ & Tidak terjadi autokorelasi \\
\hline
\end{tabular}

Sumber : Pengolahan Data SPSS (2021)

Dari tabel 6 diatas dapat diketahui nilai Durbin-Watson sebesar 1,784, sedangkan nilai dL sebesar 1,2221, nilai Du sebesar 1,7259 didapat dari tabel DurbinWatson signifikasi $5 \%$ dengan $\mathrm{k}=4$ dan $\mathrm{n}=$
35 (banyaknya data penelitian). Sehingga dapatl disimpulkan bahwa dU $<$ DW < 4dU $(1,7259<1,784<2,2741)$ maka dapat disimpulkan hasilnya tidak terjadi masalah autokorelasi pada model regresi.

\section{Hasil Uji Heteroskedastisitas}

Tabel 7 Hasil Uji Heteroskedastisitas

\begin{tabular}{|c|c|c|c|}
\hline Variabel & Sig. & Standar & Keterangan \\
\hline Struktur & 715 & & Tidak terjadi \\
\hline Modal & 0,715 & 0,05 & Heteroskedastisitas \\
\hline $\begin{array}{l}\text { Manajemen } \\
\text { Laba }\end{array}$ & 0,991 & $>0,05$ & $\begin{array}{c}\text { Tidak terjadi } \\
\text { Heteroskedastisitas }\end{array}$ \\
\hline Likuiditas & 0,600 & $>0,05$ & $\begin{array}{c}\text { Tidak terjadi } \\
\text { Heteroskedastisitas }\end{array}$ \\
\hline $\begin{array}{l}\text { Beban } \\
\text { Pajak } \\
\text { Tangguhan }\end{array}$ & 0,793 & $>0,05$ & $\begin{array}{c}\text { Tidak terjadi } \\
\text { Heteroskedastisitas }\end{array}$ \\
\hline
\end{tabular}

Sumber : Pengolahan Data SPSS (2021)

Dari hasil tabel 7 diatas dapat dilihat bahwa korelasi antara variabel Struktur Modal, Manajemen Laba, Likuiditas, dan Beban Pajak Tangguhan dengan Unstandardized Residual memiliki nilai signifikansi (Sig 2-tailed) lebih dari 0,05. Karena signifikansi lebih besar dari 0,05 dapat disimpulkan bahwa tidak terjadi masalah heteroskedastisitas.

\section{Hasil Regresi Linier Berganda}

Tabel 8 Hasil Uji Analisis Regresi Linier Berganda

\begin{tabular}{lc}
\hline \multirow{2}{*}{ Variabel } & Unstandardized \\
\cline { 2 - 2 } & $\mathrm{B}$ \\
\hline (Constant) & 0,030 \\
Struktur Modal & 0,059 \\
Manajemen Laba & 0,005 \\
Likuiditas & 0,027 \\
Beban Pajak Tangguhan & $-6,986$ \\
\hline
\end{tabular}

Sumber : Pengolahan Data SPSS (2021)

Dari tabel 8 Dapat diketahi bentuk persamaan model regresi penelitian :

$\mathrm{Y}=0,030+0,059 \mathrm{X} 1+0,005 \mathrm{X} 2+0,027 \mathrm{X}_{3}$ $-6,986 X_{4}$

Nilai konstanta bernilai 0,030, hal ini menunjukkan bahwa jika semua variabel 
independen (struktur modal, manajemen laba, likuiditas dan beban pajak tangguhan) bernilai konstan atau sama dengan 0 , maka kinerja keuangan akan bernilai o,330.

Struktur Modal bernilai 0,059. Artinya setiap kenaikan variabel struktur modal sebesar 1 satuan, dengan asumsi variabel lainnya lainnya dianggap konstan, akan menaikkan tingkat kinerja keuangan sebesar 0,059.

Manajemen Laba bernilai 0,005. Artinya setiap kenaikan variabel manajemen laba sebesar 1 satuan, dengan asumsi variabel lainnya lainnya dianggap konstan, akan menaikkan tingkat kinerja keuangan sebesar 0,005.

Likuiditas bernilai 0,027. Artinya setiap kenaikan variabel likuiditas sebesar 1 satuan, dengan asumsi variabel lainnya lainnya dianggap konstan, akan menaikkan tingkat kinerja keuangan sebesar 0,027 .

Beban Pajak Tangguhan bernilai 6,986. Artinya setiap kenaikan variabel beban pajak tangguhan sebesar 1 satuan, dengan asumsi variabel lainnya lainnya dianggap konstan, akan menaikkan tingkat kinerja keuangan sebesar 6,986.

\section{Hasil Uji Kelayakan Model}

\section{Hasil Uji F}

Tabel 9 Hasil Uji F

\begin{tabular}{ccccc}
\hline Model & $F_{\text {hitung }}$ & $F_{\text {tabel }}$ & Sig. & Ket. \\
\hline Regression & 14,572 & $>2,690$ & O,000 & Model layak \\
\hline Sumber : Pengolahan Data SPSS (2021)
\end{tabular}

Dari tabel 9 diperoleh df $1=($ jumlah variabel -1$)$ atau $(5-1=4)$, dan df $2=(n-k-$ 1) atau $(35-4-1=30)$. Maka diperoleh $\mathrm{F}_{\text {tabel }}$ sebesar 2,690, artinya $\mathrm{F}_{\text {hitung }}>\mathrm{F}_{\text {tabel }}$ sebesar $14,572>2,690$, dengan nilai signifikansi 0,000 < 0,05 maka Ho ditolak. Jadi dapat disimpulkan bahwa struktur modal, manajemen laba, likuiditas dan beban pajak tangguhan secara bersamasama berpengaruh terhadap kinerja keuangan.

\section{Hasil Uji Hipotesis (Uji t)}

Tabel 10 Hasil Uji Hipotesis

\begin{tabular}{lcccc}
\hline Hipotesis & $t_{\text {hitung }}$ & $t_{\text {tabel }}$ & Sig. & Keterangan \\
\hline H1 & 1,767 & $<2,042$ & 0,087 & Diterima \\
H2 & 0,028 & $<2,042$ & 0,978 & Diterima \\
H3 & 5,385 & $>2,042$ & 0,000 & Ditolak \\
H4 & $-3,477$ & $<-2,042$ & 0,002 & Ditolak \\
\hline
\end{tabular}

Sumber : Pengolahan Data SPSS (2021)

Berdasarkan hasil perhitungan table 10 diatas diperoleh hasil :

Struktur Modal sebagai variabel dependen mempunyai nilai $-\mathrm{t}_{\text {tabel }}<\mathrm{t}_{\text {hitung }}<$ $t_{\text {tabel }}(-2,042<1,767<2,042)$ sehingga Ho diterima. Dengan diterimanya Ho, maka $\mathrm{H} 1$ ditolak. Sedangkan nilai signifikansi $\mathrm{H} 1$ $>0,05(0,087>0,05)$, maka dapat disimpulkan bahwa $\mathrm{H} 1$ ditolak, yang artinya struktur modal tidak berpengaruh terhadap kinerja keuangan.

Manajemen Laba menunjukkan nilai $-t_{\text {tabel }}<t_{\text {hitung }}<t_{\text {tabel }}(-2,042<0,028<$ 2,042) sehingga Ho diterima. Dengan diterimanya Ho, maka $\mathrm{H} 2$ ditolak. Sedangkan nilai signifikansi $\mathrm{H} 2>0,05$ $(0,978>0,05)$, maka dapat disimpulkan bahwa H2 ditolak, yang artinya manjemen laba tidak berpengaruh terhadap kinerja keuangan.

Likuiditas dapat diketahui nilai $t_{\text {tabel }}>$ $t_{\text {hitung }}(5,385>2.042)$ sehingga Ho ditolak. Dengan ditolaknya Ho, maka $\mathrm{H}_{3}$ diterima. Sedangkan nilai signifikansi $\mathrm{H}_{3}<0,05$ $(0,000<0,05)$. Dari hasil pengujian diatas, dapat disimpulkan bahwa $\mathrm{H}_{3}$ diterima, yang artinya likuiditas berpengaruh terhadap kinerja keuangan. 
Beban Pajak Tangguhan memiliki nilai $-t_{\text {hitung }}<-t_{\text {tabel }}(-3,477<-2,042)$ atau $t_{\text {hitung }}>t_{\text {tabel }}(3,477>2,042)$ sehingga Ho ditolak. Dengan ditolaknya Ho, maka $\mathrm{H}_{4}$ diterima. Sedangkan nilai signifikansi $\mathrm{H}_{4}$ $<0,05(0,002<0,05)$. Dari hasil pengujian di atas, dapat disimpulkan bahwa $\mathrm{H}_{4}$ diterima, yang artinya beban pajak tangguhan berpengaruh terhadap kinerja keuangan.

\section{Hasil Uji Koefisien Determinasi (R2)}

Tabel 11 Hasil Uji Koefisien Determinasi

\begin{tabular}{cc}
\hline Adjusted R Square & Keterangan \\
\hline o,615 & Berpengaruh 61,5\% \\
\hline
\end{tabular}

Sumber : Pengolahan Data SPSS (2021)

Tabel 11 menunjukan hasil pengujian Variabel ukuran struktur modal, manajemen laba, likuiditas dan beban pajak tangguhan memiliki persentase sumbangan pengaruh terhadap variabel dependen kinerja keuangan sebesar $61,5 \%$. Sedangkan sisanya sebesar $38,5 \%$ dipengaruhi oleh variabel yang tidak dimasukkan dalam penelitian ini.

\section{Pembahasan}

Pengaruh struktur modal terhadap kinerja keuangan

Hipotesis pertama menyatakan struktur modal tidak berpengaruh terhadap kinerja keuangan. Hal ini dikarenakan perusahaan dapat menghasilkan profit jika perusahaan dapat menjual barang atau jasa nya kepada konsumen potensial, dimana konsumen dalam membeli barang atau jasa tidak pernah melihat berapa banyak hutang perusahaan tersebut. Jadi, besar atau kecilnya struktur modal perusahaan tidak mempengaruhi kinerja keuangan.
Hasil penelitian ini sejalan dengan penelitian yang telah dilakukan Efendi dan Wibowo (2017) yang menyatakan bahwa struktur modal tidak berpengaruh terhadap kinerja. Sedangkam hasil penelitian ini tidak sejalan dengan penelitian yang dilakukan oleh (Petty, 2020) dan (Hartoyo, 2018) yang menyatakan bahwa struktur modal berpengaruh terhadap kinerja keuangan.

\section{Pengaruh manajemen laba terhadap kinerja keuangan}

Hipotesis kedua menyatakan manajemen laba tidak berpengaruh terhadap kinerja keuangan. Hal ini menunjukkan semakin baiknya perusahaan dalam melakukan aktivitas manajemen laba, tidak dapat mendongkrak kinerja keuangan perusahaan, dalam hal yang memiliki hubungan dengan tujuan melakukan manajemen laba adalah untuk memperbaiki laporan keuangan perusahaan yang tidak sama dengan kondisi yang sebenarnya.

Hasil penelitian ini sejalan dengan penelitian yang dilakukan oleh (Epi, 2017) dan (Rahayu dan Sari, 2018) yang menunjukkan bahwa manajemen laba tidak berpengaruh terhadap kinerja keuangan. Sedangkan hasil penelitian yang telah dilakukan oleh (Erawati dan Ndoen, 2019) yang mengemukakan bahwa manajemen laba berpengaruh terhadap kinerja keuangan.

\section{Pengaruh likuiditas terhadapi kinerjai keuangan}

Hipotesis ketiga menyatakan likuiditas berpengaruh terhadap kinerja keuangan. Hal ini berarti kemampuan perusahaan dalam memenuhi kewajiban jangka pendeknya dengan aktiva lancar 
yang dimilikinya menunjukkan tingkat keamanan kreditor jangka pendek atau kemampuan perusahaan dalam membayar hutang-hutangnya. Perusahaan dapat memanfaatkan aktiva lancarnya sebaik mungkin untuk memenuhi kebutuhan perusahaan sehingga tidak banyak menganggur. Hal ini mengindikasikan bahwa jika likuiditas semakin tinggi, yang berarti perusahaaan semakin likuid, maka kinerja keuangan perusahaan semakin tinggi pula.

Hasil penelitian ini sejalan dengan penelitian yang telah dilakukan oleh Fajaryani dan Elly (2018) dan D. P. Rahayu (2019) yang menyatakan bahwa likuiditas berpengaruh terhadap kinerja keuangan. Sedangkan hasil penelitian ini berentangan dengan penelitian yang telah dilakukan oleh Petty (2020) yang menyatakan likuiditas tidak berpengaruh terhadap kinerja keuangan.

\section{Pengaruh beban pajak tangguhan terhadap kinerja keuangan}

Hipotesis keempat menyatakan beban pajak tangguhan berpengaruh terhadap kinerja keuangan. Hal ini berarti dengan adanya manajemen pajak yang baik atas beban pajak tangguhan maka kinerja keuangan perusahaan dapat meningkat. Pengakuan pajak tangguhan dapat mengurangi laba bersih perusahaan pada tahun sebelumnya namun akan meningkatkan laba perusahaan tahun berikutnya karena beban pajak sudah diakumulasikan pada tahun sebelumnya.

Hasil penelitian ini sejalan dengan penelitian yang telah dilakukan oleh Elyzabet dan Lauw (2016) dan Husnah dan Dini (2018) yang menyatakan bahwa beban pajak tangguhan berpengaruh terhadap kinerja keuangan. Sedangkan hasil penelitian ini bertentangan dengan penelitian yang telah dilakukan oleh (Bhaktiar dan Hidayat, 2020) yang menyatakan bahwa tidak terdapat pengaruh pajak tangguhan terhadap kinerja keuangan.

\section{KESIMPULAN}

Hasil dari penelitian ini menunjukkan bahwa struktur modal tidak berpengaruh terhadap kinerja keuangan. Manajemen laba tidak berpengaruh terhadap kinerja keuangan. Likuiditas berpengaruh terhadap kinerja keuangan dan beban pajak tangguhan berpengaruh terhadap kinerja keuangan. Variabel independen yang digunakan dalam penelitian ini struktur modal, manajemen laba, likuiditas dan beban pajak tangguhan hanya dapat menjelaskan variabel dependen (kinerja keuangan) sebesar $61,5 \%$ dengan hasil tersebut dapat disimpulkan bahwa masih banyak variabelvariabel yang dapat mempengaruhi kinerja keuangan.

\section{Saran}

Diharapkan pada penelitian selanjutnya tidak menggunakan populasi hanya pada perusahaan manufaktur sektor industri barang konsumsi sub sektor makanan dan minuman saja, melainkan juga menggunakan populasi dari perusahaa dan sektor lainnya. Hal ini bertujuan agar jumlah sampel yang diperoleh lebih banyak dari sampel pada penelitian ini, sesuai dengan kriteriai yang sudah ditetapkan sebelumnya.

Diharapkan pada penelitian selanjutnya penulis dapat menambahkan variabel-variabel lain yang berpengaruh terhadap kinerjai keuangan. Misalnya variabel ukuran perusahaan dan umur perusahaan. 


\section{Daftar Pustaka}

Andriani P.J.A. Akuntansi Pajak. Jakarta: Salemba Empat, 2012.

Bhaktiar, Fransiscus Felix, and Vinny Stephanie Hidayat. "Pengaruh Pajak Tangguhan dan Perencanaan Pajak Terhadap Kinerja Perusahaan." Jurnal Akuntansi (Universitas Kristen Maranatha) 12, no. 2 (November 2020): 265-276.

Brigham F, and Houston J. Dasar-dasar Manajemen Keuangan. 8. Jakarta: Salemba Empat, Buku 2, 2001.

Epi, Yus. "Pengaruh Ukuran Perusahaan, Struktur Kepemilikan Manajerial dan $_{i}$ Manajemen Laba Terhadapi Kinerja Perusahaan Property dan Real Estate yang Terdaftar pada Bursa Efek Indonesia." Riset \& Jurnal Akuntansi (Politeknik Ganesha), Februari 2017.

Elyzabet I. Marpaung, and Lauw Tjun Tjun. "Pengaruh Pajak Tangguhan dan Tax to Book Ratio Terhadap Kinerja Perusahaan." Jurnal Akuntansi 8, no (Mei 2016): 16-38.

Erawati, Teguh, and Ketcia Ndoen. "Pengaruh Strukrtur Modal, Manajemen Laba, Likuiditas dan Pajak Tangguhan Terhadap Kinerja Keuangan Perusahaan." Jurnal Akuntansi Pajak Dewantara 1 (Mei-Agustus 2019).

Fahmil I. Analisis Laporan Keuangan. Bandung: Alfabeta, 2011.

Fajaryani, Ni Luh Gede Sri, and Elly Suryani. "Struktur Modal, Likuiditas, dan Ukuran Perusahaan Terhadap Kinerja Keuangan Perusahaan." Jurnal Riset Akuntansi Kontemporer 10, no. 2 (Oktober 2018): 74-79.

Gustian, Dani. "Pengaruh Pertumbuhan Perusahaan, Keputusan Investasi,
Dan Keputusan Pendanaan Terhadap Nilai Perusahaan." Jurnal Akuntansi 5, no.1 (2017).

Hani, S. Teknik Analisa Laporan Keuangan. Medan: UMSU Press, 2015.

Husnah, Vidiya Asmaul, and Dini Widyawati. "Pengaruh Pajak Tangguhan dan Tax Book Ratio Terhadap Kinerja Perusahaan." Jurnal Ilmu dan Riset Akuntansi 7, no. 4 (April 2018).

Jensen, M C, and Meckling W. "Theory of the firm : Manageria behavior, agency castand ownership structure." journal of Finance Economic, 1976: 305-360.

Kasmir. Analisis Laporan Keuangan. Jakarta: PT. Raja Grafindo Persada, 2015.

Kusumajaya D.K. "Pengaruh Struktur Modal dan Pertumbuhan perushaan terhadap profitabilitas dan nilai perusahaan pada perusahaan manufaktur di Bursa Efek Indonesia." Tesis (Program Pasca Sarjana Universitas Udayana), 2011.

S. Munawir, Drs., Akuntan, 1981, Analis laporan keuangan, Penerbit Liberty Yogyakarta

Petty Arisanti. "Pengaruh Struktur Modal, Likuiditas, dan Ukuran Perusahaan Terhadap Kinerja Keuangan pada Perusahaan Manufaktur Subsektor Keperluan Rumah Tangga yang Terdaftar di Bursa Efek Indonesia (BEI) Periode 2014-2018." Kompetensi 14, no.1 (April 2020).

Purwana \& Hidayat (2016). Studi Kelayakan Bisnis. Jakarta: Rajawali Pers.

Rahayu, Dwi Puji. "Pengaruh Ukuran Perusahaan, Struktur Modal, dan Likuiditas terhadap Kinerja Keuangan pada Perusahaan 
Makanan dan Minuman Yang Tercatat di Bursa Efek Indonesia (BEI) Tahun 2013-2017." Jurnal Akuntansi dan Keuangan Kontemporer 2, no. 1 (Mei 2019).

Rahayu, Maryati, and Bida Sari. "Kepemilikan Institusional, Manejemen Laba dan Leverage Terhadap Kinerja Perusahaan." Jurnal Ekonomi dan Bisnis 2, no. 1 (Maret 2018): 67-78.

Riyanto, Bambang. Dasar-dasar Pembelajaran Perusahaan Yogyakarta: BPFE, 2001.

Scott, and R William. Financial Accounting Theory. Canada Prenticel Hall: Fifth Edition, 2009.

Soehardi, S., \& Untari, D. T. (2020). The Effect of Covid-19 Pandemic on Hotel Employees, Hotel Occopancy Rates and Hotel Tax Income in Jakarta, Indonesia. Systematic Reviews in Pharmacy, 11(12), 964972.

https://doi.org/10.31838/srp.2020 .5 .138

Waluyo. Akuntansi Pajak : Edisi 5. Jakarta : Salemba Empat, 2014.

William, R, and Scott. Financial Accounting Theory. Canada : Prestice Hall: Second Edition, 2000.

Subramanyam K.R, and John J. Wild. Analisis Laporan Keuangan. Translated by Dewi Y. Jakarta: Salemba Empat, 2014.

Sucipto. "Penilaian Kinerja Keuangan." Jurnal Akuntasi (Universitas Sumatera Utara), 2003.

Tandio, and Lidyawati. "Pengaruh Komponen-Komponen Pembentuk Pajak Tangguhan Terhadap Manajemen Laba Perusahaan Manufaktur di BEI." Skripsi (Fakultas Bisnis Universitas WIMA), 2014. 